\title{
The Effect of Audiovisual Learning System on Self-Efficacy and Critical Thinking Ability in Science Lessons on Human Digestive System Materials Science
}

\author{
Yasin, Abin Syamsudin, Daeng Arifin, Waska Warta \\ Universitas Islam Nusantara, Bandung, Indonesia \\ Universitas Islam Nusantara, Bandung, Indonesia \\ Universitas Islam Nusantara, Bandung, Indonesia \\ Universitas Islam Nusantara, Bandung, Indonesia \\ Email: yasinimy3@gmail.com, abin_syamsuddin@upi.edu, daengaripin@uninus.ac.id and \\ waskawarta@uninus.ac.id
}

\section{ARTICLE INFO}

Date received : 03

January 2021

Revision date : 02

February 2021

Date received : 01 March

2021

\section{Keywords:}

Audio Visual Media

Learning System

Self-Efficacy

And Critical Thinking

Ability

\begin{abstract}
Students' critical thinking ability in teaching and learning activities on human digestive system material is still low, where students are less skilled in collecting and analyzing data, relevant facts and identifying problems, so students have difficulty in solving problems with alternatives that fit the logic. Based on the results of the hypothetical test analysis obtained thit $>t$ daf (1.67), then accept. $\mathrm{Hi}$ means that there is an influence on the use of audiovisual learning media on critical thinking ability in human digestive system materials in grade VIII students of SMP Negeri 1 And SMP Negeri 2 Sindang Indramayu Regency. From the calculation of $\mathrm{t}$ test above obtained $\mathrm{t}$ count $=4,957$ while $\mathrm{t}$ table at the level of trust $95 \%$ (significance $5 \%$ ) with $\mathrm{dk}$ numerator is 1.70. Because t count $(4,957)>t$ table $(1,70) \mathrm{Hi}$ accepted means there is an influence on the use of audiovisual learning media on self-efficacy in human digestive system materials in grade VIII students smp negeri 1 Filled And SMP Negeri 2 Sindang Indramayu. The result of this study is a description of the efficacy of students of grade VIII SMP Negeri 1 Filled And SMP Negeri 2 Sindang Indramayu Regency, by using audiovisual media learning system in human digestive system materials belongs to high category. There is an influence of audiovisual media learning system on self-efficacy on human digestive system materials in students VIII SMP Negeri 1 Filled And SMP Negeri 2 Sindang Indramayu.
\end{abstract}

\section{INTRODUCTION}

Teaching and Learning activities are the process of interaction between learners and the environment with the achievement of behavioral changes that include the cognitive, affective and psychomotor spheres have not achieved something expected. The process of biology learning only demands and emphasizes on the achievement of student learning outcomes in the form of cognitive realms with the acquisition of grades after carrying out learning, thus leading to the undevelopment of students' thinking abilities, especially students' critical thinking skills in learning and understanding the subject matter.

Critical thinking is applying rational, high thinking activities, which include analyzing, synthesizing, recognizing problems and solving them, concluding, and

\begin{tabular}{ll}
\hline How to cite: & $\begin{array}{l}\text { Yasin, et. al. (2021) The Effect of Audiovisual Learning System on Self-Efficacy and Critical } \\
\text { Thinking Ability in Science Lessons on Human Digestive System Materials Science, 2(3). } \\
\text { https://doi.org/10.46799/jsss.v2i3.135 }\end{array}$ \\
\hline E-ISSN: & $2721-5202$ \\
\hline Published by: & Ridwan Institute
\end{tabular}


evaluating. Self-efficacy is a person's reality regarding his ability to perform certain specific tasks. Self-efficacy is a concept of self and relates to one's perception of one's ability and expertise in dealing with a particular task (Alex, 2003). This statement is in accordance with the opinion of Zulkosly (2009), that a person's self-efficacy level will affect the actions taken.

Students also do not develop verbal skills because during learning students do not actively participate in expressing their opinions. This shows that there needs to be an innovation of a applied and more meaningful learning model that can explore students' critical thinking skills and selfefficacy. The high level of self-efficacy is influenced by many other factors besides the teaching and learning process, in the learning process there are learning components that affect each other including the use of learning media. Munadi (2008: 125) explains that "Audiovisual media is a tool in the form of images and sounds in receiving a message, so that students can gain useful knowledge and experience to achieve the goals they want to achieve".

The proper use of audio visual media in learning activities can improve good interaction and communication between teachers and students, foster interest and motivation to learn, improve the effectiveness of the delivery of learning materials and increase students" learning motivation.

Students who have a high interest in learning, passion or motivation to learn and understand the subject matter as well as the effectiveness of the use of audiovisual media can train students to improve critical thinking skills and self-efficacy. Students who are motivated to learn will attempt to make observations or observais, define terms and analyze arguments relating to the subject matter.

Initial observations made by researchers at SMP Negeri 1 And SMP Negeri 2 Sindang Indramayu, the ability to think critically of students in biological subjects in processing information while the learning process is still low. Students are less skilled in collecting data, analyzing relevant data and facts, identifying learning problems, students having difficulty in solving problems with alternatives that fit the logic, as well as low analysis of arguments or opinions related to the subject matter.

Based on the above, the study seeks to see the reality of how the use of audiovisual learning media can improve critical thinking skills in the subjects of Biological Sciences in human digestive system materials in students of SMP Negeri 1 Filled And SMP Negeri 2 Sindang Indramayu Regency.

\section{METHOD}

The method used in this study is the experimental method. This study used quasy design experiments with pre-post test control groups. The research design can be described as:

Pre-post test control group design

Group Pre Test Treatmen Post

Test

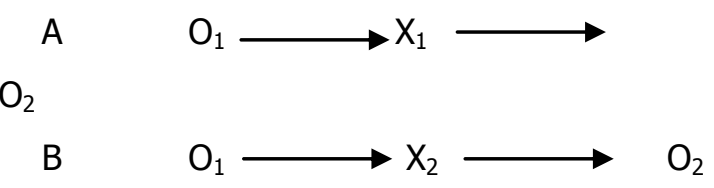

information:

$A=$ Control group

$\mathrm{B}=$ Experimental groups

$\mathrm{O}_{1}=$ Initial tests were given to the experimental and control group

$\mathrm{O}_{1}=$ Final Test given to experimental and control group

$\mathrm{X}_{1}=$ Visual media treatment

$\mathrm{X}_{2}=$ Audio visual media treatment

The population taken in this study is all students of grade VIII SMP Negeri 1 Filled Indramayu school year 2020/2021 which amounts to 4 classes, namely grade VIII A to VIII D which amounts to 200 students. The samples used were grade VIII A smp negeri 1 filled students who numbered 35 students as experimental classes using audiovisual media and SMP Negeri 2 The session of grade VIII A students totaling 35 students as a control class using Powerpoint media.

The data collection techniques in this study are as follows:

1. The test with a total of 10 questions given to students, conducted at the end of the learning used to know the critical thinking ability of students, 
where students answer questions about essays

2. Questionnaire is a list of statements to respondents that are closed, where each question has been provided alternative answers, so that respondents simply choose one of the alternative answers that are considered in accordance with empirical reality. Questionnaires are used to determine the picture of selfefficacy after carrying out audio media visual

The observation technique used is the observation sheet. Observations are carried out in the learning process, observations are used for the implementation of learning with the implementation of audio visual media against self-efficacy and critical thinking skills

\section{RESULTS AND DISCUSSION}

The effectiveness of the teaching and learning process is influenced by the factors of the learning methods and media used. The two are interconnected, where the selection of certain methods will affect the type of media to be used, in the sense that there must be conformity between the two to realize the purpose of learning. There are other things that also need to be considered in media selection, such as: learning context, learning characteristics, and the expected tasks or responses of learners. As stated by (Arsyad, 2005) learning media is everything that concerns software and hardware that can be used to deliver lesson materials that can stimulate the mind, feelings, attention and interests of learners in such a way that the learning process becomes more effective.

According to (Astutik, 2005) Self efficacy is generally associated with selfesteem because both are aspects of judgment with one's success or failure as a human being. An individual's belief in his or her ability to perform the tasks or actions necessary to achieve certain results is related to self-efficacy.

According to (Alex, 2003), selfefficacy is not related to the prowess, but relates to the individual's belief in what can be done with the prowess he has no matter how much. Self-efficacy emphasizes the components of self-confidence that a person has in the face of future situations that contain blurring, un foreseeable, and often stressful. Although self-efficacy has a great causal influence on our actions, self-efficacy combines with the environment, previous behaviors, and other personal variables, especially the expectation of results to produce behavior. Self efficacy will affect some aspects of a person's cognition and behavior. Self-efficacy can lead to different behaviors among individuals with similar abilities because Self-Efficacy affects choices, goals, problem solving, and persistence in trying.

According to (Bandura, 1986), (Bandura, 1997) that: "Self-Efficacy is the result of cognitive processes in the form of decisions, beliefs, or rewards about the extent to which an individual estimates his or her ability to carry out certain tasks or actions necessary to achieve the desired results".

According to (Takwin \& Martiasa, 2001), critical thinking ability is an effort that is deliberately done actively, systematically, and following the principle of logic and considering various points of view to understand and evaluate information.

According to (Achmad, Subekti, \& Atmini, 2007), critical thinking is the ability to apply rational, high thinking activities, which include the activities of analyzing, synthesizing, recognizing problems and solving them, concluding and evaluating.

The quality of education is generally defined as the nature of education in accordance with the provisions to meet the users of education, namely students / students, parents, society, government, and other interested parties. Qualty control is required in maintaining and supervising the quality of the process including all supporting components. Educational institutions (schools) are people changing instituation, which in its work system is always met with uncertainty and interdependence. The purpose of the mechanism of action (production) in educational institutions with technology can not be ensured because the state of input and the environment are never the same.

Humans build science and technology, starting from observing natural phenomena in the most elementary way, using the naked eye, arising from the desire to utilize them for their survival. 
Furthermore, humans develop a variety of methods, procedures, and systems that are increasingly complex, in line with the complexity of the problems they face, trying to trace the characteristics of natural phenomena in more depth and detail.

Science and technology are the content of the educational curriculum, while the curriculum itself is a collection of human experiences that are organized systematically and systemically as a result or fruit of human cultural work.

Therefore, the selection of distribution and content of the curriculum in an educational program is essentially the determination of content or knowledge relevant to the needs and demands of society.

That is, the development of science and technology as one of the characters of socio-cultural development will give patterns and colors for the planning and implementation of educational development. Thus science and technology are values that are sourced to the mind and logic, while art is sourced on feelings or aesthetics.

The development of science and technology will directly become the content I material of education, while indirectly equipping the community with the ability to solve the educational problems faced.

The philosophical foundation is related to the focus of research "The influence of audio visual media prison system on critical thinking of students and self-efficacy in the field of science and biology studies (Quantitative experiment research study at SMP Negeri 1 Losarang and SMP Negeri 1 Filled Indramayu District)". Learning media is one of the supporters of the learning process. Media is used as a tool for educators to create environmental conditions in learning more effectively and efficiently, so as to generate desire and motivation and increase the interest in learning in order to encourage students in applying and integrating various concepts that have been learned. Learning media is everything that can convey the message from the source in a planned manner, so that there is a conducive learning environment where the recipient can conduct the learning process effectively and efficiently. Messages delivered through the media in the form of content or teaching materials must be accepted by the recipient of the message (students), using one or a combination of some of their sensory tools. Even better if all senses are able to receive the content of the message delivered. With the advancement of technology allows to produce interactive learning media that is interesting and fun for the teaching and learning process. Multimedia gives a pleasant impression to help the learning process in remembering it (Suheri, 2006).

The use of media is one of the important components in the learning process in schools. The use of media is considered important because it helps achieve learning objectives. In an effort to improve the learning process to be effective and functional, the function of learning media is very important to be utilized. The use of media in the learning process is intended to increase students' digestibility to the information or learning materials provided, therefore, the preparation of learning media becomes one of the responsibilities of teachers.

Through learning technology, educators will easily simulate learning close to the real conditions of an abstract learning material, for example, the explanation of the concept of photosynthetic light-dark reaction below will not be easily explained to students. How can the concept of molecular in sensing be explained well. Through learning technology, various concepts, various studies can be explained perfectly.

The quality of education is strongly influenced by the learning process in the classroom. Classroom learning takes place as a process of interaction with all situations around an individual Someone who has learned will have an impact on behavior changes that are relatively permanent and show maximum learning outcomes. Education in schools is expected not only to develop rational inteligance, which is a model of understanding that is usually understood by students but also to develop the skills that exist in them, especially selfefficacy.

According to (Bandura, 1986) Bandura in (Zimmerman, 2000), there are three aspects of efficacy in human beings, namely (1) level, where there is a difference in self efficacy that is lived by each 
individual may be due to differences in demands faced. The demands of the task present varying degrees of difficulty or difficulty to achieve optimal performance. (2) The generality of an individual may judge themselves confidently through various activities or only in certain functions.

(3) Strength of experience has an influence on one's self efficacy or related to one's belief in his own abilities (Neuman \& Baron, 2003).

The mechanism of self-efficacy contains an explanation of how self-efficacy in individuals. Self-perception of self-efficacy that takes place in an individual's existence as a decisive function in how an individual behaves, his mindset and the emotional reactions they experience.

Astutik (2003: 59), reveals cognitive processes, cognitive processes such as thinking processes, including acquisition, organization, and use of information. Most human actions start from a pre-thought sesuau. Individuals who have high selfefficacy are more than happy to imagine about success. On the contrary, individuals with low Self-Efficacy imagine more failures and things that can hinder the achievement of success. The form of personal goals is also influenced by the assessment of selfability. The more a person perceives himself or herself to be able to then the more individuals will form efforts in achieving their goals and the stronger the individual's commitment to his goals.

Individuals motivate themselves and direct actions through previous stages of thought. Confidence in self-ability can influence motivation in several ways, namely determining the goals that have been determined by individuals, how much effort they put in, how resilient they are in the face of their difficulties and resilience in the face of failure. There are three theories that explain the motivation process. The first theory is causal attributions. This theory focuses on causes that affect individual motivations, efforts, and reactions. Individuals who have high Self-Efficacy when dealing with failure tend to consider such failures to be due to inadequate efforts. On the contrary, individuals with low Self-Efficacy tend to consider their failures to be due to their limited abilities. The second theory, outcomes experience, which states that motivation is formed through expectations. Usually individuals will behave according to their beliefs about what they can do. The third theory, goal theory, whereby by forming a goal in advance can increase motivation.

The ability to think is one of the things that distinguishes man from other beings, the Quality of Thought is one human being to another (Fahim \& NasrollahiMouziraji, 2013). However, not all natural thought processes lead to human superiority, but rather critical thinking that leads to improvement and progress for humans.

Critical thinking is a cognitive activity of a person by involving rational thinking and skill in realizing an idea (Ennis, 1985) (Syaifudin \& Utami, 2011); (Keskin-Samanci, Özer-Keskin, \& Arslan, 2014). Ideas in thought are expressed in the form of oral and written arguments. The ability to analyze arguments received as well as in the preparation of arguments is one of the necessary components in critical thinking skills (Halpern, 1998) (Herlanti, 2014) (Mustakim, Zulfiani, \& Herlanti, 2014). Critical thinking ability is closely related to the quality of the arguments prepared. Good argument quality consists of statements with fact-filled data, reasoning that connects data with statements and is supported by knowledge, as well as strengthening arguments (Venville \& Dawson, 2010).

1. Audiovisual Media In Education

According to (Nomura, Darmawan, Yamaji, \& Imada, 2017) The development of Educational Audio Visual has a big influence in educational technology. The development of this concept is also in line with and broadly the development of techniques and science concepts that are more concerned, at first hardware and equipment. The rapid development of audiovisuals occurred after the Second World War. Educational practitioners believe there are results of improved learning outcomes through audiovisual media (Lange \& Gilbert, 1968) (Squiers, 1990).

With the establishment of the department of Audiovisual Instructional 
(DAVI) and the Association for Educational Communications and Technology (AECT) provides a definition of audiovisual interrelationship in educational engineering. One of his views is to emphasize concepts based on material engineering and a systematic approach to developing teaching.

Visual aids in learning were used in the 19th century whose literature was taken from the concept of:

a. Teaching Aid

Concept of Teaching Aids oriented to audiovisual techniques in the development of teaching presentation (Sharma, BORN, \& Mcbeath, 1977).

b. Visualizing

A learning curriculum that provides concrete presentation concepts in teaching and learning. (Ely, 1970)

These visual aids are images, models, objects, or devices that present concrete or tangible experiences that students can see, with the aim of:

a) Recognize, build, enrich or clarify abstract concepts.

b) Develop the desired attitude

c) Simulate an activity

Hoban promotes a curriculum that incorporates concrete learning experiences based on the use of visible tools. This requires teachers to use it in the classroom or because of discussions about how to integrate teaching materials into the curriculum.

Therefore, according to the author audiovisual media is everything that can be used in the form of hearing and vision to channel the message and can stimulate the mind, can arouse the spirit, attention, and will of students so as to encourage the learning process in students.

According to (Djamarah \& Zain, 2010) Audiovisual media can be distinguished into 4 are as follows:

1) Silent audiovisual, which is a medium that displays sound and still images such as: sound slides, story frame films and sound printing

2) Motion audiovisual, which is a medium that can display elements of sound and moving images such as: sound movies and cassette videos.
3) Pure audiovisual, i.e. both sound and image elements come from a single source such as cassette video movies

4) Audiovisual is not pure, i.e. that the sound and image elements come from different sources, such as sound frame movies whose image elements come from the source of the projector slides and the sound elements sourced from the tape recorder. Other examples are sound strip movies and sound prints.

2. Critical Thinking Ability

Thinking is a process by which new mental representation is formed through the transformation of information with complex interactions of mental attributes such as judgment, abstraction, logic, imagination, and problem solving.

According to (Takwin \& Martiasa, 2001), critical thinking ability is an effort that is deliberately done actively, systematically, and following the principle of logic and considering various points of view to understand and evaluate an information.

Characteristics of critical thinking ability According to (Zubaidah, 2010), characteristics of critical thinking ability are as follows:

a) Get to know in detail the parts of the whole

b) Good at detecting problems

c) Able to distinguish relevant ideas from irrelevant ones

d) Able to distinguish facts from fiction or opinions

e) Able to identify differences or information gaps

f) Can distinguish logical and illogical arguments

g) Able to develop criteria or standards of data assessment

h) Likes to collect data for factual proof.

According to (Zubaidah, 2010), indicators of critical thinking ability are as follows:

1) Search for a clear statement of each question

2) Find a reason

3) Trying to know the information well

4) Using sources that have credibility and mention them 
According to (Achmad et al., 2007), indicators of critical thinking ability are as follows:
a. Organize the mind and articulate it clearly, logically or plausibly
b. Distinguish between conclusions based on valid logic and invalid logic
c. Identifying data adequacy and facts
d. Understanding the difference between reasoning and rationalization
e. Trying to anticipate the possible consequences of various activities
f. Understand ideas according to their level of confidence
g. Able to learn independently and have an unending attention in his work
h. Apply problem solving techniques in other domains than he has learned
i. Can arrange informal representations of problems into formal ways that can be used to solve problems
j. Can express an irrelevant verbal argument and express an essential argument.

k. Questioning a view and questioning the implications of a view

Sensitive to the difference between the validity and intensity of a trust and the validity and intensity it holds

3. Self-Efficacy

According to (Alex, 2003) Self efficacy is not related to the proficiency at its disposal, but relates to the individual's belief in what can be done with the prowess he has no matter how great. Self-efficacy emphasizes the components of self-confidence that a person has in the face of future situations that contain blurring, un foreseeable, and often fraught with pressure. Although self-efficacy has a great causal influence on our actions, self-efficacy combines with the environment, previous behaviors, and other personal variables, especially the expectation of results to produce behavior. Self efficacy will affect some aspects of a person's cognition and behavior. Self-efficacy can lead to different behaviors among individuals with similar abilities because selfefficacy affects choices, goals, problem solving, and persistence in trying.

According to (Bandura, 1986) self-efficacy can be grown and studied through four main sources of information, namely:
1) Experience success
2) Other people's experiences
3) Verbal persuasion
4) Psychological condition.
5) Learning

In fact, teaching is not only to convey the subject matter, but also to be interpreted as the process of organizing the environment so that students learn. The meaning of teaching is often termed learning. This suggests that in the process of teaching and learning learners should be used as the center of the activities.

According to (Udin, 2008), learning is an activity that is carried out to analyze, facilitate and improve the intensity and quality of learning in students. Therefore, learning activities are closely related to the type of nature, and the type of learning and the results of the learning. Learning should result in learning, but not all learning processes occur because of learning. Learning potential occurs also in the context of socio-cultural interactions in the community.

In improving the quality of learning, we must pay attention to some components that affect learning, those components, are as follows:
a) Students, covering socioeconomic, cultural and geographical environments, intelligence, personalities, talents and interests.
b) Teachers, including educational background, work experience, teaching expenses, economic conditions, work motivation, commitment to duty, discipline and creative.
c) Curriculum.
d) Educational facilities and infrastructure, including props / practical equipment, laboratories, libraries, skill rooms, counseling guidance rooms, UKS rooms and function rooms.
e) School Management, including 
classroom management, teacher

management, student

management, facilities and training, improved discipline, and leadership.

f) Management of learning process, including teacher appearance, mastery of materials/curriculum, use of learning methods/strategies, and utilization of learning facilities.

g) Fund Management, including budget planning, source of funds, use of funds, reports and supervision of.

h) Monitoring and Evaluation, including the Principal as a supervisor in his school, the school superintendent and the school committee as the supervisor.

i) Partnerships, including school relationships with government agencies, relationships with businesses and community leaders, and other educational institutions.

In the realities of our daily lives we are often faced with situations where good and bad problems become so complicated. The reality of life that is not always easy forces us to grapple with moral choices that are not necessarily as easy as sorting between black and white. Life is now increasingly complex, change very quickly, competition is inevitable exchange of unstoppable values. The advancement of philosophy, science, technology, has resulted in an increasingly advanced culture, the process is called cultural globalization. But the increasingly advanced culture of globality turns out to have a huge impact on the moral aspect.

Because the system that makes our mind become complex is getting older, when we try to ponder it could be the thing that we have been thinking about complexly or the thing that we are trying to solve with complex thinking it actually only needs a simple solution and settlement.

1) Human Digestive System Materials

Combining the dimensions of knowledge and dimensions of cognitive processes, teachers can formulate the learning objectives they want to achieve and how successful they are. Ari (2005) stated that there are two alternatives that can be taken in the formulation of learning objectives and then map into matrks to know which aspects are adequate and that still need to be considered. Second, map the goals you want to achieve in the matrix and write them down in detail. This strategy is not only suitable for beginners who are just learning to formulate learning objectives but also for people who are experienced in formulating learning goals based on old taxonomy. Through this strategy, teachers determine what kind of knowledge students will learn and which cognitive processes will be achieved. Then, a more detailed formulation was made. Thus, the second strategy is recommended to be used because by utilizing the matrix of learning objectives as a grid of formulating objectives, teachers will be encouraged to expand the spread of their learning objectives.

2) Implementation of Audiovisual Media Learning System

Based on the results of observation analysis or observation of students' learning activities and teacher teaching skills, teachers have done their best to implement every step of visual media (power point) in the control group and audiovisual media in the learning experiment group. In control groups with the application of visual media (power points), students are less actively involved in discussing and completing learning assignments, so students only passively accept and memorize lesson materials. While the experimental group with the application of audiovisual media is actively involved and focused on observing the video that is imagined by teachers to collect and analyze relevant data and facts in the field, discuss and complete learning tasks and present the results of discussions and observe videos of the human digestive system to students of other groups.

3) Implementation of audiovisual media Learning System can increase selfefficacy 
Learning activities using audiovisual media the teacher asks students to focus on viewing the learning video of the human digestive system with students actively observing or focusing and enthusiastically viewing video impressions about the human digestive system, thus improving aspects of students' confidence in human digestive system learning.

The teacher asks students to underline words that are considered complex and difficult, then write in their respective books so that students are motivated to ask questions related to words or terms that do not understand so as to improve the motivational aspect by having a high spirit to learn and understand the subject matter.

Then the teacher gives the student the opportunity to draw up questions about what has been seen from the screening of a learning video, ask students to discuss from the exposure of the material through the impression of a video, students play an active role in discussing, completing the task sheet, expressing opinions / ideas / ideas and improving aspects of student affection in learning activities.

Furthermore, the teacher checks the understanding of ecosystem materials, provides students with the opportunity to explore more information through references, checks students' understanding of human digestive system materials and provides opportunities for students to argue from the results of discussions (confirmations), ask students to work groups and conduct discussions and express opinions based on the airing of a learning video of the human digestive system, and teachers respond to the results of student discussions and provide actual confirmation so as to improve aspects of selection in improving students' critical thinking skills in system materials. human digestion. Based on table 4.2 above, self-efficacy of students after carrying out learning with audiovisual media use in the experimental group has reached $74 \%$ including high categories, with an average score between 3.6 - 3.9. This proves that experimental classes have a positive response to the use of audiovisual media where students are passionate about learning by identifying and formulating research problems, conducting investigations and observations in the field, collecting and analyzing data and trying to solve tasks and solve problems based on data and facts obtained from the field. While the control group has a negative response to the application of group discussion methods where students only passively accept and listen to the lesson materials provided by the teacher, and record a summary of the lesson materials.

From the calculation of $t$ test above obtained t count $=4,957$ while $\mathrm{t}$ table at the level of trust $95 \%$ (significance $5 \%)$ with dk numerator $=\mathrm{n}-2=34-$ $2=32$ is 1.70 . Because $t$ count $(4,957)$ $>\mathrm{t}$ table $(1,70) \mathrm{Hi}$ accepted means there is an influence on the use of audiovisual learning media on selfefficacy in human digestive system materials in grade VIII students smp negeri 1 Filled and SMP Negeri 2 Sindang Indramayu District.

4) Implementation of audiovisual media Learning System can improve students' critical thinking skills

Teaching and Learning activities using the teacher's audiovisual media learning system ask students to focus on viewing the learning video of the human digestive system with students actively observing or focusing and enthusiastically viewing video impressions about human digestive system learning, thus improving the ability to observe or observe objects shown in the human digestive system learning video. This is shown from the results of the test ability to observe or observation in the experimental group with the use of audiovisual media obtained an average score of 78 better than in the control class with the application of visual media (power points) that obtained an average score of 65.33. This is evidenced by the experimental class trying to be active in observing audiovisual media about 
Biology science learning that is aired by teachers to collect data and facts relevant in solving learning problems.

The teacher asks students to underline words that are considered complex and difficult, then writes in their respective books so that students are motivated to ask questions related to words or terms that do not understand so as to improve the ability to define terms and consider a definition. This is demonstrated by the ability to define terms and consider a definition in the experimental group with the use of audiovisual media obtaining an average score of 76 better than in the control class with the application of visual media (power points) which obtained an average score of 67. This is evidenced by students in the experimental class in defining terms relating to the mausia digestive system, formulating and considering a definition of the human digestive system inferring the subject matter of the results of discussions and presentations of study groups.

Then the teacher gives the student the opportunity to draw up questions about what has been seen from the viewing of a learning video, ask students to discuss from the exposure of the material through the impression of a video, students play an active role in discussing, completing the task sheet, expressing opinions / ideas / ideas and improving the ability to analyze an argument. This is demonstrated by the ability to analyze arguments in the experimental group with audiovisual media usage scoring an average score of 90 better than in the control group with the application of visual media (power points) which obtained an average score of 70 . This is evidenced by students in the experimental group trying to discuss and complete learning assignments, ask and answer questions and express opinions related to the learning materials of the human digestive system, and students are actively involved in providing analysis of arguments or opinions of other students related to the learning materials of the human digestive system.

Furthermore, the teacher checks the understanding of human digestive system learning materials, provides students with the opportunity to explore more information through references, checks students' understanding of human digestive system learning materials and provides opportunities for students to argue from the results of discussions (confirmation), ask students to work in groups and conduct discussions and express opinions based on the airing of a learning video of human digestive system learning, and the teacher responds to the results of the student discussion and provides actual confirmation thus improving the ability to identify assumptions. This was demonstrated by the ability to identify assumptions in the experimental group with audiovisual media usage achieving an average score of 84.33 better than in the control class with the application of visual media (power points) which obtained an average score of 59.33. This is evidenced by students in the experimental class actively identifying assumptions related to human digestive system learning, expressing opinions, responding to other students' answers and adding additional answers related to human digestive system learning materials.

Based on the results of testing and statistical analysis with hypothetical test data post test critical thinking ability of students by using paired t test at the level of trust (0.05) control class with the application of group discussion methods and experimental classes using audiovisual media obtained $\mathrm{t}$ hit value $(6,59)>t$ daf $(1.67)$, then accept $\mathrm{Hi}$ means that there is an influence of audiovisual media learning system on critical thinking ability in human digestive system learning materials in grade VIII students of SMP Negeri 1 Filled and SMP Negeri 2 Sindang Indramayu Regency. 


\section{CONCLUSION}

Science Learning Biology material human digestive system by using Audio Visual media against self-efficacy is quite effective. This can be seen from learning using Audio Visual media can help junior high school students to be confident in solving a problem and answering essay questions so that there is an improvement in students' learning outcomes. So it can affect the value of students' learning outcomes. This means that there is an influence on the use of audiovisual learning media on self-efficacy in human digestive system materials in grade VIII students of SMP Negeri 1 Terisi and SMP Negeri 2 In indramayu district council. This proves that the use of audiovisual media can improving self-efficacy and critical thinking ability in human digestive system materials in grade VIII students of SMP Negeri 1 And SMP Negeri 2 Indramayu District Council. There is an influence on the use of audiovisual learning media on critical thinking skills in human digestive system materials in students of Grade 1 Filled and Smp Negeri 2 Indramayu District Council. This can be seen from the analysis of the results of the essay test critical thinking ability of experimental grade students at SMP Negeri 1 Filled better than the control class namely SMP Negeri 2 Sindang Indramayu Indramayu Regency.

\section{REFERENCES}

Achmad, Komarudin, Subekti, Imam, \& Atmini, Sari. (2007). Investigasi motivasi dan strategi manajemen laba pada perusahaan publik di Indonesia. Jurnal Tema, 8(1). Google Scholar

Alex, Sobur. (2003). Psikologi umum. Bandung: Pustaka Setia. Google Scholar

Arsyad, Zulkarnain. (2005). Diagnostic problems of pleuroperitoneal tuberculosis. Acta Med Indones, 37(1), 36-38. Google Scholar

Astutik, Dwi. (2005). Pengembangan model pembinaan anak jalanan melalui rumah singgah di Jawa Timur. UNIVERSITAS AIRLANGGA. Google Scholar

Bandura, Albert. (1986). Fearful expectations and avoidant actions as coeffects of perceived self-inefficacy. Google Scholar

Bandura, Albert. (1997). The anatomy of stages of change. American Journal of Health Promotion: AJHP, 12(1), 8-10. Google Scholar

Djamarah, Syaiful Bahri, \& Zain, Aswan. (2010). Strategi Belajar Mengajar, cet. ke-4. Jakarta: PT Rineka Cipta. Google Scholar

Ely, John Hart. (1970). Legislative and administrative motivation in constitutional law. The Yale Law Journal, 79(7), 1205-1341. Google Scholar

Ennis, Robert H. (1985). A logical basis for measuring critical thinking skills. Educational Leadership, 43(2), 44-48. Google Scholar

Fahim, Mansoor, \& Nasrollahi-Mouziraji, Alieh. (2013). The relationship between Iranian EFL students' self-efficacy beliefs and critical thinking ability. Theory and Practice in Language Studies, 3(3), 538543. Google Scholar

Halpern, Diane F. (1998). Teaching critical thinking for transfer across domains: Disposition, skills, structure training, and metacognitive monitoring. American Psychologist, 53(4), 449. Google Scholar

Herlanti, Yanti. (2014). Tanya Jawab Seputar Penelitian Pendidikan Sains: Jawaban atas pertanyaan-pertanyaan mahasiswa tingkat akhir yang sering muncul dalam penelitian pendidikan sains. Yanti Herlanti. Google Scholar

Keskin-Samanci, Nilay, Özer-Keskin, Melike, \& Arslan, Orhan. (2014). Development of 'Bioethical values inventory'for pupils in secondary education within the scope of bioethical education. EURASIA Journal of Mathematics, Science and Technology Education, 10(2), 69-76. Google Scholar

Lange, C. S., \& Gilbert, C. W. (1968). Studies on the cellular basis of radiation lethality: III. The measurement of stemcell repopulation probability. 
International Journal of Radiation Biology and Related Studies in Physics, Chemistry and Medicine, 14(4), 373388. Google Scholar

Mustakim, Tri Ade, Zulfiani, Zulfiani, \& Herlanti, Yanti. (2014). Identifikasi miskonsepsi siswa dengan menggunakan metode certainty of response index (cri) pada konsep fotosintesis dan respirasi tumbuhan. Edusains, 6(2), 145-152. Google Scholar

Neuman, Joel H., \& Baron, Robert A. (2003). Social antecedents of bullying: A social interactionist perspective. Bullying and Emotional Abuse in the Workplace. International Perspectives in Research and Practice, 185-202. Google Scholar

Nomura, Yusuke, Darmawan, Andrew S., Yamaji, Youhei, \& Imada, Masatoshi. (2017). Restricted Boltzmann machine learning for solving strongly correlated quantum systems. Physical Review $B$, 96(20), 205152. Google Scholar

Sharma, M. P., BORN, W. H. VANDEN, \& Mcbeath, D. K. (1977). Studies on the biology of wild oats. II. Growth. Canadian Journal of Plant Science, 57(3), 811-817. Google Scholar

Squiers, Carol. (1990). Critical image: essays on contemporary photography; Seattle; Bay Press. Google Scholar

Suheri, Agus. (2006). Animasi multimedia pembelajaran. Jurnal Media Teknologi, 2(1), 27-33. Google Scholar

Syaifudin, Ahmad, \& Utami, Santi Pratiwi Tri.
(2011). Penalaran argumen siswa dalam wacana tulis argumentatif sebagai upaya membudayakan berpikir kritis di SMA. Lingua, 71 ). Google Scholar

Takwin, Bagus, \& Martiasa. (2001). Filsafat Timur: Sebuah pengantar ke pemikiranpemikiran Timur. Jalasutra. Google Scholar

Udin, Susan B. (2008). Isthmotectal axons maintain normal arbor size but fail to support normal branch numbers in dark-reared Xenopus laevis. Journal of Comparative Neurology, 5074), 15591570. Google Scholar

Venville, Grady J., \& Dawson, Vaille M. (2010). The impact of a classroom intervention on grade 10 students' argumentation skills, informal reasoning, and conceptual understanding of science. Journal of Research in Science Teaching, 47(8), 952-977. Google Scholar

Zimmerman, Barry J. (2000). Self-efficacy: An essential motive to learn. Contemporary Educational Psychology, 25(1), 82-91. Google Scholar

Zubaidah, Siti. (2010). Berpikir Kritis: kemampuan berpikir tingkat tinggi yang dapat dikembangkan melalui pembelajaran sains. Makalah Seminar Nasional Sains Dengan Tema Optimalisasi Sains Untuk Memberdayakan Manusia. Pascasarjana Unesa, 16, 1-14. Google Scholar

Copyright holder:
n, Daeng Arifin and

Yasin, Abin Syamsudin, Daeng Arifin and Waska Warta(2021)

First publication right:

Journal of Social Science (JSS)

This article is licensed under:

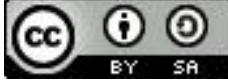

